\title{
Skin Response Location
}

National Cancer Institute

\section{Source}

National Cancer Institute. Skin Response Location. NCI Thesaurus. Code C117688.

The site in or on the body at which the skin response test or result is performed or collected. 